\title{
Redução do inóculo inicial de Sclerotinia sclerotiorum em soja cultivada após uso do sistema Santa Fé
}

\author{
Claudia Adriana Görgen(1), Ederson Antônio Civardi(2), Vilmar Antonio Ragagnin(3), \\ Américo Nunes da Silveira Neto(3), Luciana Celeste Carneiro( ${ }^{(3)}$ e Murillo Lobo Junior ${ }^{(4)}$
}

\begin{abstract}
(1)Embrapa Cerrados, Caixa Postal 08223, CEP 73310-970 Planaltina, DF. E-mail:claudiadrianagorgen@gmail.com (2)Universidade Federal de Goiás (UFG), Escola de Agronomia e Engenharia de Alimentos, Campus Samambaia, Caixa Postal 131, CEP 74001-970 Goiânia, GO. E-mail: eaccivardi@yahoo.com.br (3)UFG, Campus Jataí, Caixa Postal 03, CEP 75800-000 Jataí, GO. E-mail: vilmar.ragagnin@gmail.com, americonunesagro@yahoo.com.br, luciana.celeste.carneiro@gmail.com ${ }^{(4)}$ Embrapa Arroz e Feijão, Caixa Postal 179, CEP 75375-000 Santo Antônio de Goiás, GO. E-mail: murillo@cnpaf.embrapa.br
\end{abstract}

Resumo - O objetivo deste trabalho foi avaliar a efetividade do sistema Santa Fé na redução do inóculo inicial de Sclerotinia sclerotiorum, agente causal do mofo-branco em soja. O experimento foi realizado em Jataí, GO, nas safras de 2007/2008, 2008/2009 e 2009/2010, em lavoura comercial infestada naturalmente pelo patógeno. Foram feitas avaliações quanto ao número de escleródios germinados na superfície do solo, e quanto ao número de apotécios e estipes do patógeno. Utilizou-se o delineamento experimental de blocos ao acaso, em arranjo fatorial $(2 \times 4)$, com quatro repetições. Os tratamentos consistiram do sistema Santa Fé (milho + Urochloa ruziziensis) e do milho solteiro implantados na safrinha, em março de 2008 e 2009. Além disso, estudaram-se também quatro diferentes épocas de avaliação da germinação dos escleródios e produção de apotécios e estipes. Verificou-se que o sistema Santa Fé aumentou a proporção de escleródios menores que $2 \mathrm{~mm}$, considerados de menor infectividade, e favoreceu a redução do inóculo inicial por meio da germinação de escleródios e formação de apotécios na entressafra, o que reduziu o número de escleródios germinados e o número de apotécios em pleno florescimento durante os cultivos da soja. O sistema Santa Fé pode reduzir o inóculo inicial de $S$. sclerotiorum, e pode ser utilizado no manejo do mofo-branco da soja.

Termos para indexação: Glycine max, Urochloa ruziziensis, integração lavoura-pecuária, mofo-branco, sistema plantio direto.

\section{Reduction of Sclerotinia sclerotiorum initial inoculum in soybean grown after the use of the Santa Fé system}

\begin{abstract}
The objective of this work was to evaluate the effectiveness of Santa Fé system on reduction of the initial inoculum of Sclerotinia sclerotiorum, the causal agent of white mold in soybean. The experiment was carried out in Jataí, GO, Brazil, during 2007/2008, 2008/2009 and 2009/2010 growing seasons, in a commercial field naturally infested with the pathogen. Evaluations were done for number of sclerodia germinated on the soil surface, and for the pathogen number of apothecia and stipes. The experimental design was a randomized block, in a 2x4 factorial arrangement with four replicates. The treatments comprised the Santa Fé system use (maize + Urochloa ruziziensis), and maize as a single crop, both sown at the "safrinha" period (March 2008 and 2009). Furthermore, four evaluation dates of sclerotium germination and apothecium and stipe production were studied. The Santa Fé system increased the proportion of sclerotia smaller than $2 \mathrm{~mm}$, considered as of lower infectivity, and promoted the reduction of the initial inoculum through the germination of sclerotia and the development of apothecia between the soybean growing seasons, what reduced the germinated sclerotia and the number of apothecia in the full flowering stage during soybean growing seasons. Santa Fé system can reduce the initial inoculum of $S$. sclerotiorum, and it may be used for the management of white mold in soybean.
\end{abstract}

Index therms: Glycine max, Urochloa ruziziensis, crop-livestock integration, white mold, no-tillage system.

\section{Introdução}

A adoção de sistemas de integração lavoura-pecuária tem se expandido nos Cerrados, principalmente após o advento do Sistema Santa Fé, desenvolvido para se disponibilizar forragem verde na época seca (Vilela et al., 2003). Nesse sistema, a forrageira - geralmente espécies de Urochloa sp. (syn. Brachiaria sp.) - é consorciada com milho, sem prejuízo para a cultura anual. Além da produção de forragem para entressafra,

Pesq. agropec. bras., Brasília, v.45, n.10, p.1102-1108, out. 2010 
o Sistema Santa-Fé possibilita a obtenção de palhada de alta qualidade, adequada à condução do sistema plantio direto (SPD) em condições tropicais.

A introdução de espécies como U. ruziziensis ( $\mathrm{R}$. Germ. \& C. M. Evrard) Crins ou U. brizantha (Hochst. ex A. Rich.) Stapf., nos sistemas produtivos de grãos também é útil para o manejo de doenças causadas por patógenos do solo, tais como Sclerotinia sclerotiorum e Fusarium solani, respectivamente causadores do mofo-branco e da podridão radicular, em espécies como a soja e o feijoeiro-comum (Toledo-Souza et al., 2008; Görgen et al., 2009).

Em área altamente infestada por S. sclerotiorum, Görgen et al. (2009) determinaram a eficiência da palhada de braquiária como barreira física à produção de apotécios e a consideraram como premissa para controle biológico deste patógeno no SPD. A produção de palhada é eficiente em reduzir a população de escleródios no solo, que representam a principal fonte de inóculo e a parte fundamental no ciclo de vida do patógeno (Clarkson et al., 2003).

A severidade do mofo-branco em diferentes hospedeiros de S. sclerotiorum é, em geral, proporcional à densidade de inóculo do patógeno no solo. Portanto, a redução da população de escleródios é essencial para o controle efetivo do mofo-branco, que além disso também deve bloquear a formação de apotécios e a ejeção de ascósporos e minimizar a produção de novos escleródios pelo controle preventivo da doença na parte aérea das plantas.

Os fatores ambientais condicionantes da germinação carpogênica do escleródio incluem temperatura, umidade do solo e profundidade em que o escleródio encontra-se no solo (Liu \& Paul, 2007; Wu \& Subbarao, 2008). A espécie hospedeira também pode estimular a germinação de escleródios, por meio de exudatos radiculares e pelo microclima formado sob o seu dossel. Em zonas de clima temperado, as condições ideais partem de uma combinação de eventos úmidos e secos, baixas temperaturas e tempo (Bardin \& Huang, 2001). Em contraste, isolados oriundos dos trópicos não requerem frio no processo de germinação carpogênica. Portanto, a origem geográfica dos isolados é de fundamental importância em estudos com $S$. sclerotiorum (Bolton et al., 2006).

Existe uma ampla gama de fatores ligada ao tempo de sobrevivência, à capacidade de germinação carpogênica ou miceliogênica, à atividade enzimática, ao potencial de infecção, e à distribuição espacial de escleródios no solo (Sun \& Yang, 2000; Clarkson et al., 2003; Wu \& Subbarao, 2008). Em campo, é possível interferir sobre esses processos com práticas culturais e com um incremento do parasitismo de escleródios com agentes de controle biológico endêmicos ou aplicados na lavoura. Consequentemente, pesquisas direcionadas ao manejo de $S$. sclerotiorum costumam estar diretamente ligadas a condições climáticas e de manejo, a características de cultivo locais e a possibilidades de inviabilizar os escleródios. No Brasil, no entanto, há poucos trabalhos que demonstram a viabilidade deste controle em lavouras comerciais, com estudos realizados em médio prazo.

O objetivo do presente trabalho foi avaliar a efetividade do sistema Santa Fé na redução do inóculo inicial de S. sclerotiorum.

\section{Material e Métodos}

O experimento foi implantado em lavoura cultivada com safra de soja e safrinha de milho há mais de 10 anos, pertencente à Agropecuária Rio Paraíso, no Município de Jataí, GO, em área com histórico de alta infestação por S. Sclerotiorum, a $17^{\circ} 44^{\prime} 51^{\prime \prime S}, 51^{\circ} 35^{\prime} 33^{\prime \prime} \mathrm{W}$, à altitude de $900 \mathrm{~m}$, em solo considerado de textura muito argilosa (66\% argila, $23 \%$ silte e $11 \%$ areia).

Utilizou-se o delineamento experimental de blocos ao caso, em arranjo fatorial, com quatro repetições. As parcelas utilizadas eram de $10,50 \times 5,00 \mathrm{~m}$. Os tratamentos foram constituídos pelo sistema Santa Fé, implantado com U. ruziziensis em consórcio com milho, e pelo cultivo do milho solteiro na safrinha, para a formação de cobertura morta sobre o solo. Além disso, estudaram-se também quatro diferentes épocas de avaliação: outubro de 2008 (antes do plantio da soja), janeiro de 2009 (em pleno florescimento da soja), outubro de 2009 e janeiro de 2010.

O experimento foi conduzido com a cultura da soja durante três safras consecutivas de verão (2007/2008, 2008/2009 e 2009/2010). As variedades de soja utilizadas foram Coodetec 228(2007/2008) e TMG 123 RR (2008/2009 e 2009/2010). A semeadura ocorreu entre 12 e 15 dias após a dessecação com 2,5 L ha-1 de glifosato, sempre no mês de novembro. A adubação de base para a soja foi de $80 \mathrm{~kg} \mathrm{ha}^{-1}$ de $_{2} \mathrm{O}_{5}$ e $\mathrm{K}_{2} \mathrm{O}$, de acordo com a análise química do solo. $\mathrm{O}$ espaçamento entre linhas de plantio foi de $0,45 \mathrm{~m}$, com uso de 16 , 16 e 12 sementes por metro, nas safras 2007/2008, 2008/2009 e 2009/2010, respectivamente. A colheita foi realizada, anualmente, em março. 
Em cada safra, logo após a colheita da soja, foram semeados o milho solteiro ou consorciado com U. ruziziensis. Para a semeadura de U. ruziziensis, foram utilizados 300 pontos de valor cultural (VC), e a semeadura foi feita a lanço, um pouco antes da semeadura do milho. Para a cultura do milho, foram utilizados os híbridos DOW 2B587 e Pioneer 30K75, no espaçamento entre linhas de $0,87 \mathrm{~m}$, com uso de três sementes por metro, nas safrinhas 2008 e 2009. A adubação de base foi de 10,60 e $40 \mathrm{~kg} \mathrm{ha}^{-1}$ de $\mathrm{N}$, $\mathrm{P}_{2} \mathrm{O}_{5}$ e $\mathrm{K}_{2} \mathrm{O}$, respectivamente, e a cobertura com $\mathrm{N}$ foi de $60 \mathrm{~kg} \mathrm{ha}^{-1} \mathrm{em} \mathrm{V7.}$

A densidade de escleródios - inicial e final - foi estimada em duas ocasiões, antes da instalação do experimento, em outubro de 2007, e após a colheita da safra 2009/2010, por meio de amostras de solo coletadas com uma moldura de $0,5 \times 0,5 \mathrm{~m}$ (gabarito). $\mathrm{O}$ gabarito foi lançado aleatoriamente dentro da área de cada parcela, para coleta do solo até a profundidade de $5 \mathrm{~cm}$. Em cada parcela, foram realizadas três amostragens, e o solo foi armazenado em sacos de plástico. As amostras foram transportadas até o laboratório da Universidade Federal de Goiás, em 2007, e do Centro de Pesquisa Ambiental Zenaide Gouveia Vilela, em 2010, ambas em Jataí, GO. Nessas ocasiões, para facilitar a visualização dos escleródios, as amostras foram peneiradas em telas sobrepostas de 6 , 10 e 18 malhas por polegada (MPL) que correspondem a 6, 3,5 e $2 \mathrm{~mm}$, respectivamente. Posteriormente, os escleródios foram coletados nas diferentes frações de solo, com auxílio de pinça metálica, separados com uso de peneira de $2 \mathrm{~mm}$ (18 MPL), e quantificados.

No campo, as avaliações de escleródios germinados na superfície do solo foram realizadas em cinco ocasiões: durante o crescimento vegetativo da braquiária, após as primeiras chuvas, em outubro de 2008 e de 2009; e na presença da cultura da soja em pleno florescimento (estágio R2) em janeiro de cada ano.
Foram considerados escleródios germinados aqueles que apresentavam estipes e apotécios, ou apenas um dos dois, diferenciados e visíveis sobre o solo, a olho nu. Quando visíveis, os apotécios ou estipes foram coletados do solo para contagem do número de escleródios germinados. As avaliações foram realizadas após a definição das áreas de amostragem com lançamento aleatório do gabarito de $0,5 \times 0,5 \mathrm{~m}$ dentro das parcelas, com três subamostras por parcela.

Após a contagem dos escleródios germinados, determinou-se o número de estipes por escleródio e de apotécios por escleródio. Na avaliação na presença da cultura de soja, em janeiro, foram contados somente os apotécios que se encontravam acima da camada de palha, para quantificar o efeito da barreira física da palhada sobre o crescimento do estipe e a diferenciação do apotécio. $\mathrm{Na}$ entressafra, foram contados todos os apotécios, inclusive aqueles que se encontravam sob os restos culturais do milho safrinha, bem como, sob o dossel vegetativo da braquiária ou de plantas daninhas.

No dia anterior à dessecação, foram coletadas amostras da parte aérea da braquiária em $1 \mathrm{~m}^{2}$ por parcela, para se estimar a massa de matéria seca do sistema Santa Fé e do milho solteiro por hectare. As amostras foram colocadas em sacos de plástico e imediatamente enviadas à Embrapa Arroz e Feijão para secagem a $60^{\circ} \mathrm{C}$ por 72 horas. Todos os dados foram submetidos à análise de variância com uso do programa SAS.

\section{Resultados e Discussão}

A densidade de inóculo na área experimental, antes da aplicação dos tratamentos, foi estimada em 131,4 escleródios $\mathrm{m}^{-2}$, e considerada uniforme, após a análise de variância (Tabela 1). Assim, os tratamentos foram conduzidos sem viés.

Tabela 1. Análise de variância do número de escleródios de Sclerotinia sclerotiorum germinados e do número formado de apotécios, estipes, apotécios por escleródios e estipes por escleródios, resultantes do cultivo de soja sobre palhada de milho consorciado com braquiária (sistema Santa Fé) ou sobre palhada de milho solteiro, em quatro épocas de avaliação.

\begin{tabular}{lccccc}
\hline Fonte de variação & Escleródios germinados & Apotécios & Estipes & Apotécios por escleródio & Estipes por escleródio \\
\hline Bloco & $23,38^{\mathrm{ns}}$ & $159,05^{\mathrm{ns}}$ & $37,97^{\mathrm{ns}}$ & $38,66^{\mathrm{ns}}$ & $11,24^{\mathrm{ns}}$ \\
Braquiária & $77,36^{\mathrm{ns}}$ & $406,49^{* *}$ & $47,02^{\mathrm{ns}}$ & $953,43^{* *}$ & $84,90^{* *}$ \\
Época & $323,81^{* *}$ & $95,33^{*}$ & $466,67^{* *}$ & $177,10^{* *}$ & $197,76^{* *}$ \\
Braquiária $\times$ Época & $624,05^{* *}$ & $1.366,27^{* *}$ & $50,42^{*}$ & $601,80^{* *}$ & $4,22^{\mathrm{ns}}$ \\
Resíduo & 30,18 & 104,35 & 18,65 & 38,04 & 5,77 \\
\hline
\end{tabular}

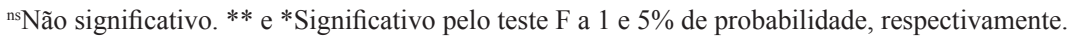


$\mathrm{Na}$ grande maioria das amostras, nenhum escleródio ficou retido na peneira com 6 MPL. Nas poucas vezes em que escleródios foram encontrados nessa malha, a quantidade não passou de 5 por amostra. Embora cerca de $80 \%$ dos escleródios tenha ficado retida na peneira de 10 MPL, aproximadamente $11 \%$ dos escleródios foram encontrados na fração de solo retida na peneira de 18 MPL (2 mm) (Tabela 2).

A massa de matéria seca do consórcio milho/ braquiária foi de 10,1 e $11,3 \mathrm{Mg} \mathrm{ha}^{-1}$, e a de milho solteiro foi de 2,4 e 3,1 $\mathrm{Mg} \mathrm{ha}^{-1}$, nos anos 2008 e 2009, respectivamente.

Na avaliação final, em março de 2010, após a colheita da soja, a densidade de inóculo na área experimental foi estimada em 147,73 escleródios $\mathrm{m}^{-2}$. No entanto, diferentemente da primeira avaliação, a maior parte dos escleródios encontrados $(63,54 \%)$ ficou retida na peneira de $18 \mathrm{MPL}$, com diâmetro menor que $2 \mathrm{~mm}$ e comprimento entre 0,5 e $5 \mathrm{~mm}$. A maioria dos $36,46 \%$ escleródios restantes ficou retida na peneira de 10 MPL. Conforme Willets \& Wong (1980) e Costa \& Costa (2006), o tempo para formação, o tamanho e a forma dos escleródios são diferenciados conforme a planta hospedeira, seu estádio fisiológico, condição nutricional, umidade relativa do ar e histórico do solo. O presente trabalho, por sua vez, demonstrou que o cultivo de espécies para a formação de palhada sobre o solo, no SPD, também influencia o tamanho e a proporção entre escleródios maiores e menores no solo. É possível, ainda, que o menor tamanho de escleródios, em soja cultivada após uso do sistema Santa Fé, afete o número de ascósporos produzidos e, como consequência, a severidade da doença, fato não avaliado neste estudo.

Em condições naturais, o escleródio pode ser formado e atingir sua maturidade funcional em diferentes períodos de tempo, que pode ser influenciado

Tabela 2. Distribuição em função do tamanho e do número de escleródios de Sclerotinia sclerotiorum por metro quadrado, coletados antes da implantação do experimento (2007) e em 2010, após três anos de cultivo de soja sobre palhada de milho consorciado com braquiária (sistema Santa Fé) ou sobre palhada de milho solteiro.

\begin{tabular}{ccccccc}
\hline Ano & \multicolumn{2}{c}{ Com braquiária } & Total & \multicolumn{2}{c}{ Sem braquiária } & Total \\
\cline { 2 - 7 } & $<2 \mathrm{~mm}$ & $>2 \mathrm{~mm}$ & & $<2 \mathrm{~mm}$ & $>2 \mathrm{~mm}$ & \\
\hline 2007 & $16,33^{*}$ & $122,79^{*}$ & 139,12 & $13,54^{*}$ & $110,21^{*}$ & 123,75 \\
2010 & 112,41 & 43,21 & 155,62 & 83,88 & 55,96 & 139,83 \\
\hline
\end{tabular}

*Significativo pelo teste $\mathrm{t}$, a $5 \%$ de probabilidade. pelas condições ambientais. Nas avaliações em campo, foram observados escleródios menores do que $2 \mathrm{~mm}$ que apresentavam apotécios. Hao et al. (2003) também relataram a produção de apotécios em escleródios deste mesmo tamanho e verificaram, ainda, que o número de apotécios produzidos é proporcional ao tamanho do escleródio de $S$. sclerotiorum.

$\mathrm{Na}$ avaliação de escleródios germinados na superfície do solo, verificou-se redução de $S$. sclerotiorum, nas quatro avaliações realizadas, em parcelas onde foi aplicado o sistema Santa Fé (Figura 1). Os tratamentos também apresentaram comportamentos diferentes, quando comparados durante o crescimento de $U$. ruziziensis e durante o florescimento da soja. Observou-se maior número de escleródios germinados sob o dossel da forrageira em outubro de 2008. A cobertura vegetal densa e uniforme formada pela braquiária, em quantidade de matéria seca superior a 7 $\mathrm{Mgha}^{-1}$, proporcionou ambiente favorável à germinação carpogênica, pelo aumento da umidade do solo, em razão da condensação d'água próxima à superfície do solo (Hao et al., 2003; Wu \& Subbarao, 2008). As temperaturas também tenderam a oscilar menos, o que também pode ter favorecido a germinação.

Na comparação das avaliações realizadas em outubro de 2008 e outubro de 2009, verificou-se redução do número de escleródios germinados na presença e aumento na ausência de braquiária (Figura 1). Além disso, observou-se redução do número de escleródios germinados sob a cultura da soja em pleno florescimento, em janeiro de 2009 e de 2010, quando cultivada sobre

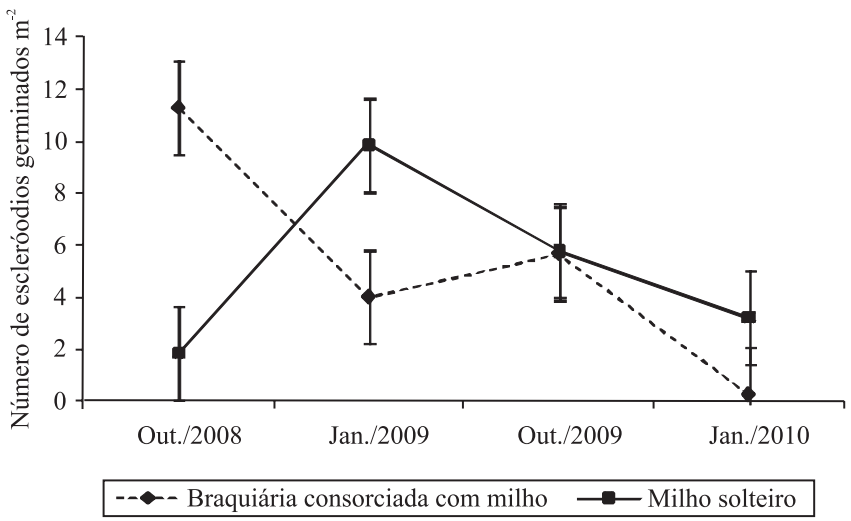

Figura 1. Número de escleródios de Sclerotinia sclerotiorum germinados na superfície do solo sob sistema plantio direto, após consórcio milho/braquiária (sistema Santa Fé) ou milho solteiro na safrinha, seguido pelo cultivo de soja, estabelecida sobre palhada desses tratamentos. 
palhada de braquiária com milho, em comparação à palhada de milho, o que mostra outra vantagem da inclusão da palha de $U$. ruziziensis no SPD.

Observou-se que havia escleródios germinados sob a cobertura com braquiária, tanto no período vegetativo como na palhada seca, o que corrobora os dados de Görgen et al. (2009). A influência de palhada de milho solteiro também foi verificada pela presença de escleródios germinados, mesmo nas parcelas onde não havia cobertura de braquiária. Os escleródios germinados foram encontrados onde havia maior concentração de restos culturais do milho conduzido na safrinha. Observou-se, ainda, que em outubro de 2009 não houve diferença quanto ao número de escleródios germinados entre o sistema de consórcio milho braquiária e o milho solteiro (Figura 1). É provável que a diminuição de escleródios viáveis no sistema Santa Fé, bem como o aumento dos escleródios após cultivo da soja da safra 2008/2009, nas parcelas com resíduos de milho safrinha solteiro, tenha favorecido esses resultados.

A palhada de braquiária bem formada pode manter a umidade do solo por maior período de tempo (Marchão et al, 2007). Alguns trabalhos têm demonstrado que a umidade do solo influencia mais a germinação carpogênica dos escleródios do que a temperatura do solo e a intensidade de luz sob o dossel; no entanto a interação desses fatores é que determina a germinação carpogênica (Sun \& Yang, 2000; Hao et al., 2003). Segundo Liu \& Paul (2007), escleródios enterrados em solos argilosos, a $15^{\circ} \mathrm{C}$, germinam em intervalos de umidade entre 15 e $50 \%$.

Um padrão semelhante à germinação de escleródios foi observado para os apotécios, nas diferentes avaliações realizadas. O número de apotécios, na presença da cultura da soja, foi semelhante apenas para a safra 2007/2008, quando a cultura foi implantada ainda na ausência dos tratamentos com o Sistema Santa Fé. Nas demais safras, houve redução gradual do número de apotécios, quando a cultura foi implantada sobre o consórcio milho/braquiária (Figura 2 A). Da mesma forma observada para os escleródios, nas avaliações de entressafra (outubro de 2008 e de 2009), o número de apotécios formados sobre o solo variou nas diferentes épocas de avaliação.

Após implantação do sistema Santa Fé, o número de apotécios formados sob a braquiária (outubro) foi sempre maior do que os formados na cultura da soja (janeiro), após dessecação da braquiária, o que torna evidente o favorecimento de gramíneas adensadas sobre a germinação carpogênica de S. sclerotiorum. Em outubro de 2008, foram estimados maior número de apotécios no sistema Santa Fé - 15,29 $\mathrm{m}^{-2}$ contra $0,79 \mathrm{~m}^{-2}$ (Figura $2 \mathrm{~A}$ ) - e maior número de apotécios por escleródio (Figura 2 B). Em outubro de 2009 esta diferença não foi verificada, pelos mesmos motivos expostos quanto à germinação de escleródios.

A presença da cobertura vegetal de milho com braquiária não impediu a formação de apotécios no cultivo de soja, em janeiro de 2009, apesar de ter sido $50 \%$ menor em comparação à soja sobre palhada de milho solteiro (Figura $2 \mathrm{~A}$ ). Esse resultado contraria os de outros estudos, em que a presença de uma barreira física impede a formação de apotécios (Ferraz et al., 1999; Kluthcouski et al., 1999; Napoleão et al., 2005), talvez pelo fato de os resultados aqui expostos terem sido obtidos em área altamente infestada por S. sclerotiorum.
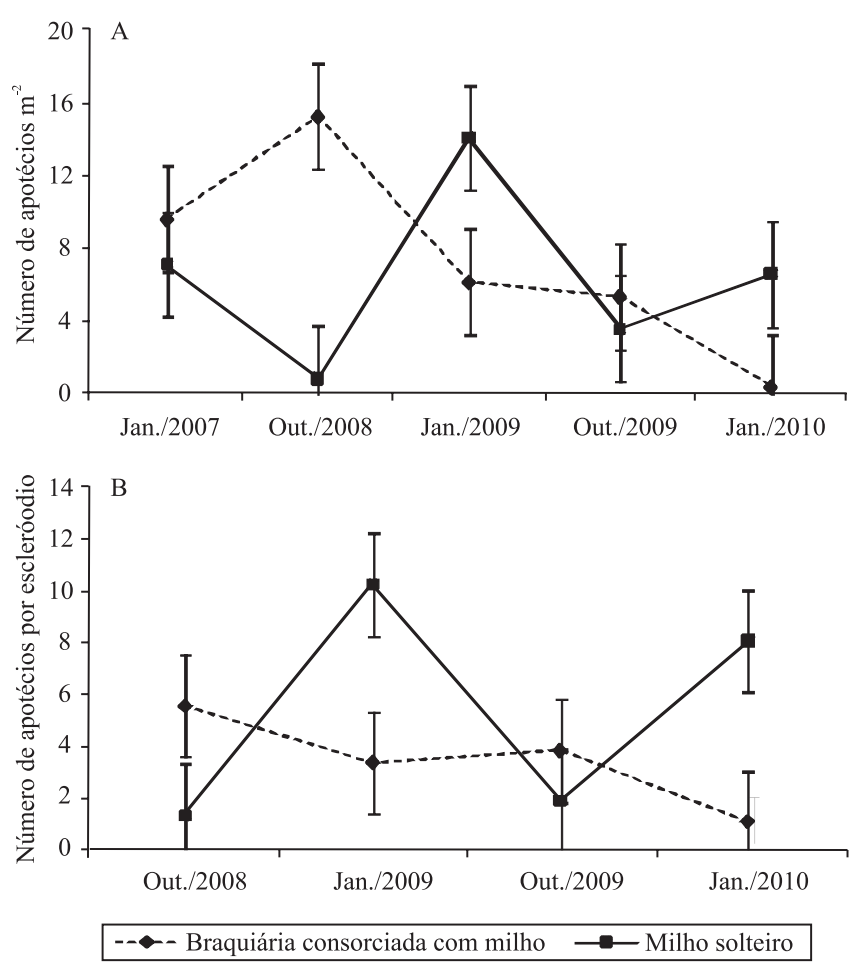

Figura 2. Número de apotécios por metro quadrado (A) e número de apotécios por escleródio de Sclerotinia sclerotiorum (B), em solo cultivado em sistema plantio direto após consórcio milho/braquiária (sistema Santa Fé) ou milho solteiro na safrinha, seguido por cultivo de soja estabelecida sobre palhada desses tratamentos. 
Verificou-se diferença no número de apotécios por escleródio, entre as diferentes épocas, em que os sistemas com consórcio milho/braquiária e milho solteiro apresentaram resultados inversos na entressafra e na safra da soja (Figura 2 B). Nas avaliações realizadas em outubro, a proporção de apotécios por escleródio foi maior nas parcelas com braquiária + milho, em 2008 e 2009. No entanto, nas avaliações em pleno florescimento da soja, o número de apotécios por escleródio foi maior nos tratamentos precedidos por milho solteiro na safrinha.

Alguns estudos correlacionam tamanhos de escleródio e quantidade de apotécios formados, a partir do princípio de que quanto maior o escleródio maior a quantidade de reservas. Isto, possivelmente, deve-se ao fato de que, durante a germinação carpogênica, os materiais de reserva dos escleródios são metabolizados, e os compostos sintetizados são usados para a formação de estipes e diferenciação dos apotécios. Os estipes podem indicar a formação de novos apotécios, cuja formação ainda não estava completa por ocasião das avaliações realizadas e, assim, alterar as proporções descritas anteriormente. Todavia, verificou-se que não houve diferença quanto ao número de estipes entre o sistema Santa Fé e o cultivo de soja sobre palha de milho solteiro, em nenhuma das avaliações (Figura $3 \mathrm{~A}$ ). Verificou-se que não houve diferença também quanto ao número de estipes por escleródio, entre os sistemas de cultivo em consórcio milho/ braquiária e milho solteiro, em nenhuma das avaliações (Figura $3 \mathrm{~B}$ ), o que pode estar ligado às semelhantes condições de clima e de cultura hospedeira.

A implantação de $U$. ruziziensis com 300 pontos de VC possibilitou a obtenção desses resultados, ora pelas condições formadas durante seu crescimento vegetativo, ora pela presença de palha obtida após sua dessecação, que produziu massa de matéria seca superior a $7 \mathrm{Mg} \mathrm{ha}^{-1}$. Este manejo, que seguiu as recomendações técnicas do sistema Santa Fé, possibilitou a desinfestação de áreas com alta densidade de inóculo de S. sclerotiorum, com eficiência aparentemente não relatada por outros autores, em áreas comerciais.

O presente trabalho representa um avanço em relação aos resultados obtidos por Görgen et al (2009), por demonstrar a germinação de escleródios sob o dossel de uma planta não hospedeira, por duas safras consecutivas, e a produção de escleródios de menor poder infectivo, no sistema Santa Fé. Esta informação indica que esse sistema pode desinfestar mais intensivamente solos com $S$. sclerotiorum, em comparação com o milho safrinha solteiro. Além disso, os resultados aqui apresentados permitem indicar o uso do Sistema Santa Fé como medida para a redução do número de apotécios formados no plantio de soja e, provavelmente, no de outras plantas hospedeiras de S. sclerotiorum. Portanto, sistemas de integração lavoura-pecuária podem ser ajustados para o manejo do mofo-branco.

Estudos mais detalhados, com intervenção sobre os condicionantes da formação dos escleródios e de sua germinação em cultivos sob SPD, além da associação do sistema Santa Fé com outras práticas de manejo do mofo-branco e redução dos riscos associados a esta doença, são necessários para um maior entendimento quanto à eficácia da integração de práticas de controle sobre o patógeno.
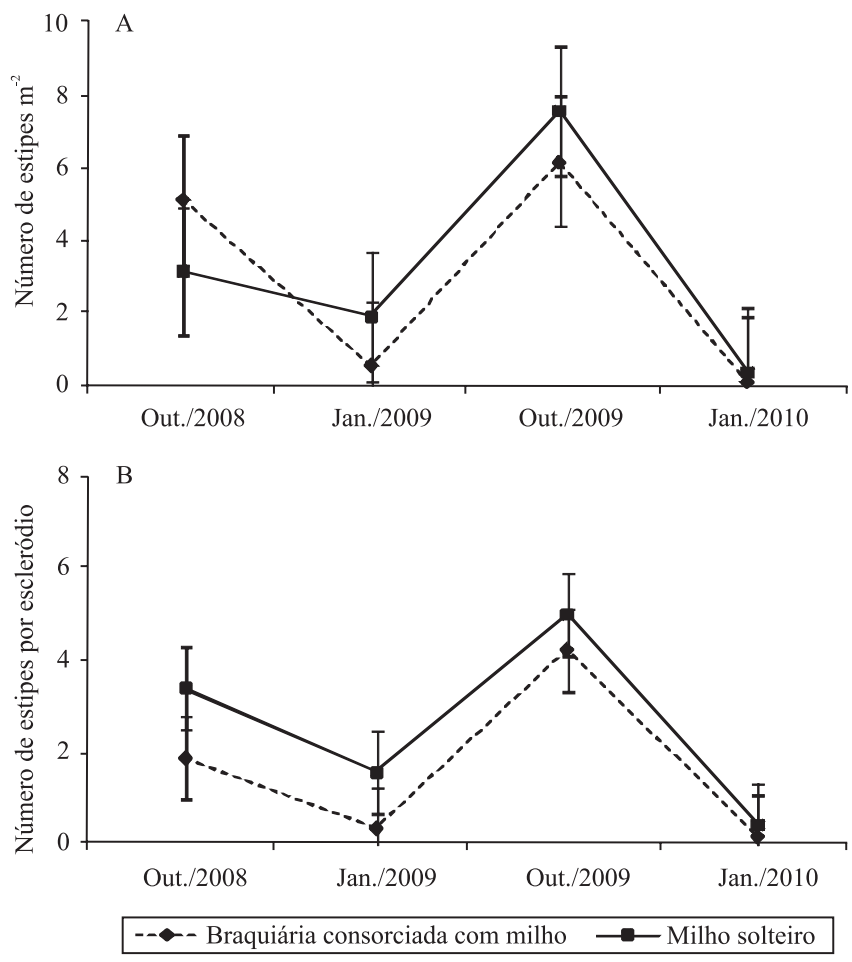

Figura 3. Número de estipes por metro quadrado (A) e número de estipes por escleródio de Sclerotinia sclerotiorum (B), em solo cultivado em sistema plantio direto, após consórcio milho/braquiária (sistema Santa Fé) ou milho solteiro na safrinha, seguido por cultivo de soja estabelecida sobre palhada desses tratamentos. 


\section{Conclusões}

1. O sistema Santa Fé pode ser utilizado para a formação de palha no SPD e na redução do inóculo inicial de Sclerotionia sclerotiorum, em áreas infestadas com o patógeno.

2. A palhada de Urochloa ruziziensis + milho, no sistema Santa Fé, resulta em maior proporção de escleródios de menor tamanho e altera a proporção entre escleródios maiores e menores do que $2 \mathrm{~mm}$, em comparação à palha de milho safrinha solteiro.

3. A germinação de escleródios e a formação de apotécios são, em geral, maiores durante o crescimento vegetativo da braquiária, em comparação ao da soja.

4. O número de estipes por escleródio de $S$. sclerotiorum não é alterado pelos sistemas de manejo.

\section{Agradecimentos}

Ao Conselho Nacional de Desenvolvimento Científico e Tecnológico e à Financiadora de Estudos e Projetos, pelo apoio financeiro.

\section{Referências}

BARDIN, S.D.; HUANG, H.C. Research on biology and control of Sclerotinia diseases in Canada. Canadian Journal of Plant Pathology, v.23, p.88-98, 2001.

BOLTON, M.D.; THOMMA, B.P.H.J.; NELSON, B.D. Sclerotinia sclerotiorum (Lib.) de Bary: biology and molecular traits of a cosmopolitan pathogen. Molecular Plant Pathology, v.11, p.1-16, 2006.

CLARKSON, J.P.; STAVELEY, J.; PHELPS, K.; YOUNG, C.S.; WHIPPS, J.M. Ascospores release and survival in Sclerotinia sclerotiorum. Mycological Research, v.107, p.213-222, 2003.

COSTA, G.R.; COSTA, J.L. da S. Influência do solo e de substratos para produção de escleródios na germinação carpogênica de Sclerotinia sclerotiorum. Pesquisa Agropecuária Tropical, v.36, p.83-87, 2006.

FERRAZ, L.C.L.; CAFÉ FILHO, A.C.; NASSER, L.C.B.; AZEVEDO, J.A. Effects of soil moisture, organic matter and grass mulching on the carpogenic germination of sclerotia and infection of bean by Sclerotinia sclerotiorum. Plant Pathology, v.48, p.77-82, 1999.

GÖRGEN, C.A.; SILVEIRA NETO, A.N. da; CARNEIRO, L.C.; RAGAGNIN, V.A.; LOBO JUNIOR, M. Controle do mofo-branco com palhada e Trichoderma harzianum 1306 em soja. Pesquisa Agropecuária Brasileira, v.44, p.1583-1590, 2009.

HAO, J.J.; SUBBARAO, K.V.; DUNIWAY, J.M. Germination of Sclerotinia minor and $S$. sclerotiorum sclerotia under various soil moisture and temperature combinations. Phytopathology, v.93, p.443-450, 2003.

KLUTHCOUSKI, J.; OLIVEIRA, I.P.; FANCELLI, A.L.; NETO, D.D.; SANTOS, R.S.M. Componentes bióticos de um campo de pesquisa sob quatro sistemas de manejo de solo. Pesquisa Agropecuária Tropical, v.29, p.33-41, 1999.

LIU, Y; PAUL, V.H. Studies on the germination of sclerotia of Sclerotinia sclerotiorum. Journal of Plant Diseases and Protection v.114, p.7-9, 2007.

MARCHÃO, R.L.; BALBINO, L.C.; SILVA, E.M. da; SANTOS JUNIOR, J. de D.G. dos; SÁ, M.A.C. de; VILELA, L.; BECQUER, T . Qualidade física de um Latossolo Vermelho sob sistemas de integração lavoura-pecuária no Cerrado. Pesquisa Agropecuária Brasileira, v.42, p.873-882, 2007.

NAPOLEÃO, R.; CAFÉ FILHO, A.C.; NASSER, L.C.; LOPES, C.A.; SILVA, H.R.L. Intensidade do mofo-branco do feijoeiro em plantio convencional e direto sob diferentes lâminas d'água. Fitopatologia Brasileira, v.30, p.374-379, 2005.

SUN, P.; YANG, X.B. Light, temperature, and moisture effects on apothecium production of Sclerotinia sclerotiorum. Plant Disease, v.84, p.1287-1293, 2000.

TOLEDO-SOUZA, E.D. de; SILVEIRA, P.M. da; LOBO JUNIOR, M.; CAFÉ FILHO, A.C. Sistemas de cultivo, sucessões de culturas, densidade do solo e sobrevivência de patógenos de solo. Pesquisa Agropecuária Brasileira, v.43, p.971-978, 2008.

VILELA, L.; MACEDO, M.C.M.; MARTHA JÚNIOR, G.B.; KLUTHCOUSKI, J. Benefícios da integração lavoura-pecuária. In: KLUTHCOUSKI, J.; STONE, L.F.; AIDAR, H. (Ed.). Integração lavoura-pecuária. Santo Antônio de Goiás: Embrapa Arroz e Feijão, 2003. p.143-170.

WILLETS, H.J.; WONG, J.A.L. The biology of Sclerotinia sclerotiorum, $S$. trifoliorum, $S$. minor with emphasis on specific nomenclature. Botanical Review, v.46, p.10-165, 1980.

WU, B.M.; SUBBARAO, K.V. Effects of soil temperature, moisture, and burial depths on carpogenic germination of Sclerotinia sclerotiorum and S. minor. Phytopathology, v.98, p.1144-1152, 2008.

Recebido em 30 de junho de 2010 e aprovado em 28 de setembro de 2010 